\section{Tiede mediassa}

Tiina Sarja (2016) Kuka oikein tietää - Kun mielipide haastoi tieteen. Helsinki: Docendo. 235 sivua.

Ulla Järvi \& Tuukka Tammi (toim.) (2016) Maito tappaa - Ja muita outoja tiedeuutisia. Tampere: Vastapaino. 216 sivua.

Tiina Raevaara (2016) Tajuaako kukaan? Opas tieteen yleistajuistajalle. Tampere: Vastapaino. 202 sivua.

TIETEEN ASEMASTA yhteiskunnassa, politiikassa ja mediassa on muutaman viime vuoden aikana julkaistu Suomessa useita kirjoja. Lisää julkaistaan jatkuvasti. Mielipide on haastanut tieteen.

Liikkeellä on iso joukko toimijoita, jotka aktiivisesti kyseenalaistavat tutkimustuloksia ja faktoja väittäen niitä yksinkertaisesti vääriksi. Mediassa on käynnissä jonkinlainen huutokilpailu totuuksista. Korkea-arvoinen poliittinen auktoriteetti voi kumota faktoja huutamalla "Fake news". Kannattajat hurraavat. Siitä saitte!

Kaikki kolme kirjaa puhuvat tiedejournalismista ja tieteen popularisoinnin vaikeudesta.

\section{MONIPUOLINEN YLEISESITYS}

Tiina Sarjan kirjoittama Kuka oikein tietää on yleisesitys tieteestä, asiantuntijuudesta, faktoista ja mielipiteistä sekä niiden keskinäisistä suhteista. Kirjoittaja lähtee liikkeelle ilmastonmuutoksesta, jota koskevia tieteellisiä faktoja vastaan käydään tuon tuostakin poliittisin ja taloudellisin perustein. Perusteluina käytetään marginaalisia tutkimustuloksia, jotka sopivat parhaiten kieltäjän omaan agendaan. Vetoamalla esimerkiksi talouden intresseihin denialistin pyrkimyksenä on saada saada tiede ja tutkijat näyttämään naurettavilta pelleiltä, joiden tutkimustulokset eivät käy arkijärkeen.

Taustalla on toki suuri yhteiskunnallinen ja kulttuurinen muutos, jossa aiemmin arvovaltaisten auktoriteettien pilkkaaminen ja kiistäminen ovat nousseet hyveiksi. Tiede on yksi arvovaltansa menettäneitä auktoriteetteja. Valinnanvapauden ajatellaan koskevan mielipiteiden lisäksi faktoja.

Taloudellista vaikuttimista tiedettä vastaan käyvät toimijat ovat taitavia luomaan tieteellisiltä näyttäviä valekiistoja, joilla saadaan viivytettyä poliittisia toimenpiteitä. Hiilipäästöt ja niiden rajoittaminen on yksi kiistan kohde.

Viime talvena Suomessa luotiin ihan oma kotoperäinen valekiista. Viivästyttääkseen tuulivoiman etenemistä perussuomalaiset vaativat keskustelua ja tutkimusta tuulivoimaloiden synnyttämien infra-aaltojen paineessa räjähtävistä lepakoista. Näin poliittinen kiista koetetaan saada näyttämään tieteelliseltä kiistalta. Yhdysvalloissa taas uskonnolliset
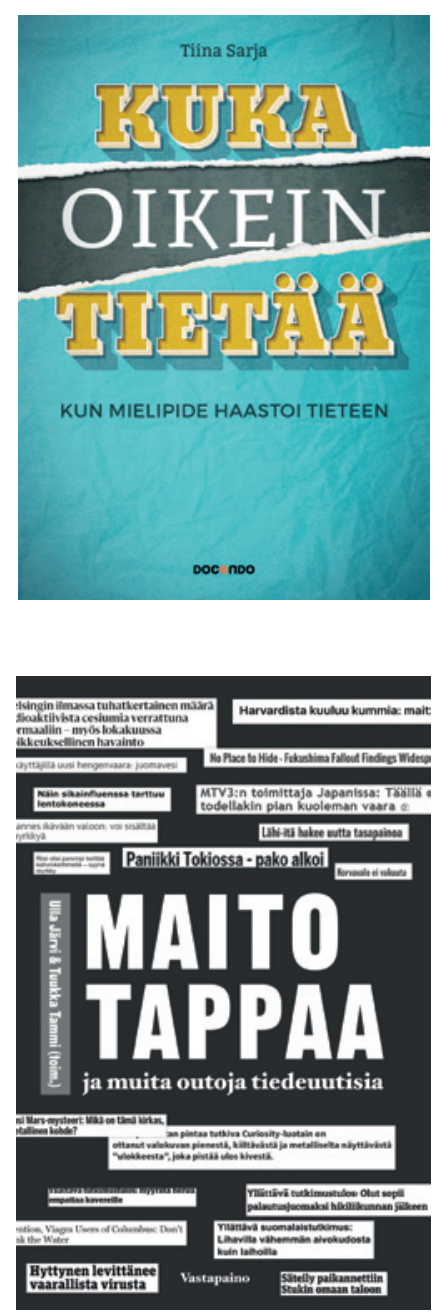

ıvälisestä tiedejulk: a Tiina Raevaara or isestä tiedejulkaises Tajuaako kukaan? n. Opas suomalaist saralla tieteen vast: yleistajuistajalle ol yritään ylläpitämään u. Vastapaino kirjo 
TiEdEJOURNALISMISSAKIN

\section{SISÄLTÖ UHRATAAN}

NÄKYVYYDELLE.

piirit ovat onnistuneet esittämään evoluutioteoriasta ja älykkäästä suunnittelusta käytävän keskustelun tieteellisenä kiistana.

Media tietenkin innostuu ja esittää kiistan tasapuolisesti kahden osapuolen välisenä kamppailuna. Tosiasiassa toisen puolen näyttö asiansa puolesta on olematon ja toisen ylivertaisen vahva. Tasapuolisuus ja kummankin osapuolen mahdollisuus saada äänensä kuuluviin kuuluvat median logiikkaan. Siten se toimii tieteen kyseenalaistajien hyväksi.

Mediassa kiistakumppaneina esiintyvät vuosikymmeniä asiaan perehtynyt tutkija ja yksityishenkilö, jolla on omaa kokemusta eli kokemusasiantuntijuutta. Systemaattinen tutkimus ja omakohtainen kokemus saavat asetelmassa saman painoarvon. Monimutkaisissa ilmiöissä kokemus on yksinkertainen ja välitön - eli tosi. Asetelma nähdään television keskusteluohjelmissa toistuvasti.

Media hakee tietoisesti vastakkainasetteluja - tarinoita, joissa on draamaa. Se tarvitsee kiinnostuksen herättämiseksi sankareita ja konnia, rohkeita totuuksien haastajia:

"Journalismin perusideaan kuuluu myös saada monenlaiset näkemykset esiin eikä vain toitottaa totuttua totuutta.

tä asioita, joihin tiedettä ja tiedeuutisia seuraavan kansalaisen olisi hyvä tutustua.

\section{TIEDEJOURNALISMIN} TAUSTOITTAJA

Hiljaisten äänien vahvistaminen ja pienen ihmisen asialla oleminen on median eräs peruslähtökohdista: journalismin ihanteiden mukaisesti pitäisi aina kertoa kunkin puolen perusteluita, eikä toimittaja ole se, joka päättää, mitkä perusteluista ovat parhaat. Ehkä kukaan ei tiedä, mutta ainakin kaikki näkökulmat on silloin tuotu lukijan arvioitaviksi." (Sarja 2016, 43.)

Valitettavasti vain iso joukko "pienistä ihmisistä" ei ole koskaan tullut ajatelleeksi, miten tiede toimii, ja mikä on tutkimuksen ja kokemuksen ero. Siitä huolimatta heidän pitäisi pystyä punnitsemaan faktoina esitettyjä väittämiä.

Sarja luonnehtii kirjassaan tieteen ja tiedon luonnetta, tieteellistä keskustelua ja tiedettä mediassa. On erinomaista, että kirjoittaja ottaa puheeksi tutkimuksen ja rahoituksen suhteen.

Tiedejutut vaativat paljon lukijaltakin, mutta ei tiedejournalisti tietenkään voi siirtää faktojen ja tulkintojen paikkansapitävyyden tarkistusta lukijoille. Lopuksi Sarja opastaa lukemaan tiedeuutisia kriittisesti ja antaa eväitä faktojen ja mielipiteiden arviointiin.

Kuka oikein tietää on yleisesityksenä erittäin monipuolinen ja ottaa puheeksi ison joukon tärkei-
Ulla Järven ja Tuukka Tammen toimittama Maito tappaa on 14 artikkelin kokoelma, jossa käydään läpi konkreettisia tiedeuutistapauksia. Kirjoittajat ovat tunnettuja tiedejournalisteja, ja joukossa on jokunen tutkijakin. He kaivavat käsittelemistään tapauksista tiedeuutisointia koskevia sudenkuoppia ja harha-askeleita.

Samalla kirja kommentoi suomalaista tiedejournalismia yleisemminkin. Tiedeuutiset laaditaan usein kärkeviksi. Ravitsemus- ja ruokatutkimukset ovat erityisen tärkeitä medioille, koska niiden tulokset kiinnostavat lähes meitä kaikkia. Ja siksi ravitsemustieto ristiriitainen ohjeineen on yleinen naurunaihe.

Näkyvyyden vuoksi tiedeuutisten otsikoinnissa haetaan raflaavuutta. Nykymediassa jokainen uutinen on kuin mikä hyvänsä tuote markkinoilla: sen täytyy herättää lukijan huomio ja saada itsensä myytyä lukijalle. Kun otsikko huutaa "Maito tappaa" tai "Juomavesi voi tapaa Viagran käyttäjän", se haluaa sanoa "Lue minut, tämä on kauheaa" tai "Lue minut, tämä on hauskaa, saat nauraa”.

Tiedejournalismissakin sisältö uhrataan näkyvyydelle. Näkyvyys tuo lukijoita, ja lukijamäärillä on rahassa mitattava arvo.

Klikkausjournalismia ruotiva Tiedetuubi-verkkolehden päätoimittaja Jari Mäkinen toteaa, että 


\section{TUtKija JOUTUU YHÄ}

\section{USEAMMIN VERKON \\ VIHAPUHEEN KOHTEEKSI.}

valtaosa klikinmetsästysotsikoista on journalististen ohjeiden vastaisia. Hänen mukaansa nykyinen tiedevastaisuus näkyy myös mediassa hällä väliä -tyylinä, mitä tulee tiedeuutisen taustalla olevien faktojen tarkistukseen.

Tiede-lehden päätoimittaja ja Helsingin Sanomien tiedetoimituksen esimies Jukka Ruukki uskoo "Pilaako viihteellisyys tiedeuutisen?" -artikkelissaan, että katteettomat otsikot ja ylilyönnit eivät ole yleensä vaarallisia. Enintään ne vahingoittavat median omaa uskottavuutta. En suhtautuisi asiaan yhtä kevyesti. Taitava toimittaja osaa laatia viihdyttävän tiedeuutisen ja pitäytyä silti faktoissa. Mutta kaikki eivät ole riittävän taitavia tehtävään.

Vaarana on se, että huomiotaloudessa tiede joutuu hölmön uutisoinnin vuoksi usein naurunalaiseksi. Tutkijat ovat hassuja, kun ne tämmöistä tutkivat. Kirjassa tuodaan esiin tutkimustulosten ja tiedeuutisten takana olevan tutkijan ongelmallinen asema internetin aikakaudella. Tutkija joutuu yhä useammin verkon vihapuheen ja vihapostituksen kohteeksi. Hän tutkii "vääriä" aiheita, kysyy "vääriä" kysymyksiä, saa "vääriä" tuloksia, tekee tulosten perusteella "väriä" johtopäätöksiä ja antaa "vääriä" suosituksia.

Tutkijaa on aiempaa helpompi solvata ja uhkailla. Hänet on helppo saada jopa pelkäämään. Suomessakin on tapauksia, joissa pakolaisia, maahanmuuttajia tai ääriliikkeitä tutkiva ei halua tuoda tutkimustaan esille mediassa. Tiedonjulkistamisen neuvottelukunnan pääsihteeri Reetta Kettunen kirjoittaa artikkelissaan vuonna 2015 tehdystä verkkokyselystä, jolla kerättiin tietoa, millaista palautetta tutkijat ovat saaneet julkisista esiintymisistään.

Tutkimustietoa olisi helppo ja hyvä levittää esimerkiksi sosiaalisessa mediassa, somessa. Tutkijoita jopa kannustetaan siihen. Mutta kaikki tutkijat eivät käytä somea tiedeviestinnässä. "Sosiaalinen media ei kiinnosta, koska siellä ei voi esittää syvällistä tietoa ja koska sosiaaliseen mediaan kuuluu yleensä asiaton keskustelu”, perustelee tutkija Kettusen artikkelissa.

"Vääriä" tutkimustuloksia esittävät tutkijat leimataan milloin fundamentalisteiksi, kommunisteiksi ja suvakeiksi, milloin taas homoiksi ja huoriksi. Populistipoliitikot ovat osaltaan legitimoimassa vihaa "väriä" tutkimuksia kohtaan, koska "väärät" tulokset eivät sovi heidän poliittiseen agendaansa.

Helsingin yliopiston viestinnän professori Esa Väliverronen paneutuu esimerkkitapauksen avulla tutkijan valmiuksiin ja vastuisiin tiedeviestinnässä. Joskus huonon tiedeuutisen jäljet johtavat sylttytehtaalle eli näkyvyyttä hakevan tai taitamattomasti viestivän tutkijan laatimaan tutkimustiedotteeseen. Kun tutkijat joutuvat yhä kovemmin kilpailemaan keskenään - myös näkyvyydestä - ei välttämättä saada huippututkimusta. Välillä syntyy rumaa jälkeä. Tutkimuksen ja tulosten liian innokas markkinointi voi olla tiedeviestinnän ongelma ja kaiken pahan alku ja juuri.

Maito tappaa kokoaa yhteen aikamoisen kasan erilaisia tapauksia tiedeuutisoinnista ja niiden ongelmista. Artikkeleiden taso vaihtelee, ja sisältö tuntuu välillä silpulta. Tappavan maidon ja Viagran lisäksi mukana on sikainfluenssaa, Fukushimaa, hulluusnäyttelyä, kirkasvalokuulokkeita, kännykkäsäteilyä, planeettoja, hiukkasia ja tiesmitä. Eittämättä on silti ollut hyvä saada tapaukset yksiin kansiin kuvaamaan sitä sekasotkua, joka tieteestä ja tutkimustuloksista on mediassa saatu aikaan.

\section{YLEISTAJUISTAJAN OPAS}

Tiina Raevaara, perinnöllisyystieteessä väitellyt biologi, on ahkera ja monitaitoinen tieteen popularisoija. Hän on kirjoittanut fiktiota ja faktaa, muun muassa erinomaisen pikkukirjan koiran historiasta Koiraksi ihmiselle.

Tajuaako kukaan? on opas tieteen yleistajuistamisesta. Tyylilajina on omakohtaisuus. Raevaara opastaa tieteen yleistajuistamisen saloihin viittaamalla usein omiin kokemuksiinsa kirjoittajana ja siihen, miten hän itse menettelee eri tapauksissa. 
Raevaara antaa esimerkin lähestymistavastaan Koiraksi ihmiselle -kirjan motivoinnilla ja näkökulmalla:

"Koirat kiinnostavat ihmisiä, niin paljon meillä on niitä lemmikkeinä. Kirjoittamalla koirasta pystyin kirjoittamaan myös ihmisestä itsestään. Koiran ja ihmisen menneisyys kietoutuu toisiinsa tiukasti." (s. 30.)

Tämä on hyvä vinkki sekä tieteen popularisoijalle että tutkijalle. Näkökulman valinnalla on iso merkitys tutkimuksen kuten myös siitä kirjoitettavan jutun viehätyksessä ja kiinnostavuudessa.

Raevaaran lähtökohta on sen hyväksyminen, että tieteen yleistajuistaminen on eräänlaista tieteen kaupallistamista, vaikka kaupallisuuden eetos sopiikin huonosti tieteeseen. Tiede kun on enimmäkseen hidasta ja harkitsevaa, ja moneen kertaan varmentavaa. Raflaavuudella ei tieteessä pitäisi olla mitään arvoa.

Tieteellistä tietoa on tarjolla yhä enemmän. Jonkun vain olisi pystyttävä tekemään se kiinnostavaksi, eli tarjoilemaan tutkimustieto sopivassa asussa potentiaalisille lukijoille. Raevaara ajattelee, että tieteen muokkaaminen kilpailukykyiseksi on tieteen puolustamista: sen osoittamista, että tiede on merkityksellistä tavalliselle ihmiselle.

Vaikka Raevaaran kirja on vetävästi kirjoitettu, se ei varsinaisesti ole yleistajuinen tietokirja vaan alaotsikkonsa mukaisesti opas. Se sopii lukemiseksi niin varsinaisille popularisoijille ja tietokirjailijoille kuin tutkijoillekin. Tutkimusartikkelikin nimittäin voi olla sujuvasti kirjoitettu ja helposti lähestyttävä.

Raevaara kannustaa tieteen yleistajuistajia sosiaaliseen mediaan. Tiedejutulle on helppoa saada lukijoita somessa. Kiinnostunutta lukijakuntaa riittää. Lisäksi huonosti tulkitut tutkimukset ja suoranaiset virheet tulevat nopeasti korjatuiksi somessa. Tieto mahdollisista virheistä ja epätarkoista tulkinnoista leviää nopeasti ja saa asiantuntijat ja faktantarkastajat liikkeelle. Palaute on nopeaa, joskin usein samalla tylyä ja asiatonta.

Tajuaako kukaan? sisältää kymmenen kohdan tarkistuslistan, jota noudattamalla voi välttyä ainakin tavallisimmilta vahingoilta somessa. Esimerkiksi ironia sopii niin huonosti nettikeskusteluun, että sen välttäminen säästää monilta virheiltä ja väärinkäsityksiltä.

Tiede taipuu monenlaiseen visualisointiin, minkä vuoksi se sopii hyvin mediaan, Raevaara päättelee. Visualisointi on tietenkin oma taitolajinsa, mutta viestimme yhä enemmän kuvien välityksellä, eikä tiedeviestinnän ole hyvä jäädä siinä jälkeen.

Raevaara opastaa lehtijutun rakentamisen saloihin esimerkkien avulla. Ne havainnollistavat ja konkretisoivat, miten lehtijuttu tai tietokirja rakennetaan ja yleistajuisuutta toteutetaan. Mallintamisesta hyötyisivät yliopistoopiskelijatkin opinnäytetöitä laatiessaan, alasta riippumatta. Selkeä ja harkittu muoto on eduksi mille hyvänsä tekstille.

HEIKKI SILVENNOINEN

VTT, professori

Turun yliopisto 